\title{
A DEMOCRACIA NÃO ESTÁ MORRENDO: FOI $O$ NEOLIBERALISMO QUE FRACASSOU
}

\author{
Luiz Carlos Bresser-Pereira \\ Professor Emérito da Fundação Getúlio Vargas. São Paulo, SP, Brasil. \\ E-mail:bresserpereira@gmail.com \\ Orcid: 0000-0001-8679-0557
}

http://dx.doi.org/10.1590/0102-051079/111

\section{Introdução}

Afinal Donald Trump não foi reeleito, mas, mesmo que tivesse sido, parece-me necessário criticar a tese da morte gradual da democracia em países desenvolvidos, porque nesses países a democracia foi uma conquista popular que as elites econômicas aceitaram há cerca de um século; são democracias consolidadas. Nesses países, e naqueles de renda média como o Brasil, que já completaram sua revolução capitalista e têm uma experiência democrática, a regra do jogo é a democracia. Populistas de direita, como Trump e Bolsonaro, a ameaçam, mas a probabilidade de que eles se perpetuem no poder de forma autoritária é mínima. A tese do fim gradativo da democracia é aplicável a países como Hungria, Polônia e Turquia, onde as eleições são mantidas, entretanto os direitos civis e o processo eleitoral vêm sendo minados por governantes autoritários. Contudo é uma tese equivocada em relação aos países ricos porque desvia a atenção do problema principal que essas democracias enfrentam: a forma neoliberal de organização econômica do capitalismo. Eu compreendo a inconformidade de muitos americanos com a eleição em 2016 de uma pessoa 
tão incapaz, violenta, má, porque eu também não me conformo com a eleição em meu país de um político ainda mais inaceitável sob um ponto de vista civilizado, no entanto isto não justifica que confundamos a "democracia liberal" com o capitalismo neoliberal, que confundamos a parte com o todo. Apenas países em profunda crise podem eleger pessoas como Trump e Bolsonaro; porém, meu argumento é que essa crise não é principalmente política, mas sim econômica e social. A causa da crise que hoje nos rodeia não acontece porque as instituições políticas democráticas falharam e sim porque as instituições econômicas fracassaram e tiveram consequências deletérias no plano social e político. Não foi a democracia que fracassou, foi a forma neoliberal que o capitalismo assumiu desde 1980 e que hoje enfrenta uma crise terminal. A democracia certamente enfrenta problemas em países nos quais ela já está consolidada, principalmente nos Estados Unidos, onde ela vem se deteriorando desde os anos 1980, e no Brasil, onde essa deterioração é mais recente, no entanto grande. ${ }^{1}$ Quando a qualidade de uma democracia diminui, ela se torna mais facilmente alvo de grupos minoritários neofascistas e populistas de direita; porém, não é difícil ver a resistência de americanos e brasileiros frente ao autoritarismo de seus governantes, e não existem fatos históricos novos de caráter político que possam ter levado tanto as classes populares como as elites econômicas a preferir um regime autoritário. Já o mesmo não pode ser dito do neoliberalismo. Foi a emergência desta forma histórica do capitalismo, que não é simplesmente conservadora, mas sim agressiva, desestabilizadora e desestruturante, que vem deixando os cidadãos insatisfeitos, inseguros e ansiosos.

\footnotetext{
1 Em seu livro, O pêndulo da democracia, Leonardo Avritzer (2019, p. 12), talvez o analista mais agudo da democracia brasileira, entende que "observamos no Brasil um processo contínuo de degradação institucional semelhante à aquele discutido por Levitsky e Ziblatt”. É verdade, mas a questão é saber se a democracia brasileira é suficientemente forte para enfrentar essa ameaça.
} 
O capitalismo implica a construção de suas duas instituições básicas - o Estado moderno e o mercado, este último incluindo os mercados domésticos e o mercado mundial. Uma construção difícil, sujeita a crises periódicas, mas também relativamente bem-sucedida porque, após a Segunda Guerra Mundial, levou os países ricos a reduzir a desigualdade, melhorar a estabilidade econômica e alcançar uma taxa de crescimento razoável. Na década de 1970, porém, surgiram novos problemas - em particular a concorrência de países em desenvolvimento que passaram a exportar produtos manufaturados - que exigiram mudanças e adaptações. O que vimos, no entanto, foi um retrocesso: a substituição da coalizão fordista que a Escola de Regulação estudou em grande profundidade por uma coalizão de classes estreita, financeiro-rentista e neoliberal, cujo projeto era reduzir a remuneração direta e indireta dos trabalhadores.

Há um fundo de verdade na tese do desaparecimento gradual da democracia: o populismo de direita está em alta não apenas nos países ricos, mas também nos de renda média como Turquia, Hungria e Polônia, onde o espírito antidemocrático pode ser mortal para a democracia. Por que, entretanto, esse populismo emergiu? Não surgiu da própria democracia, mas da forma perversa e ineficiente de capitalismo que as elites econômicas liberais dos países ricos impuseram a seus próprios países e a outros países dependentes. Simplesmente denunciar o populismo é infrutífero; entendê-lo como uma consequência do fracasso do neoliberalismo, entretanto, pode ser esclarecedor. O neoliberalismo fracassou em melhorar os padrões de vida e fornecer segurança adicional a toda a população. $O$ fracasso de um capitalismo "reformista" cujas reformas são a contrarreforma do Estado do Bem-Estar. O fracasso de uma forma de organização econômica do capitalismo associada a alta instabilidade financeira, redução do crescimento e aumento brutal da desigualdade econômica. Uma forma de organização 
econômica do capitalismo - liberalismo econômico - para a qual existe uma alternativa histórica no nível econômico, o desenvolvimentismo, e no nível político, a social-democracia - a alternativa econômica de intervenção moderada mas estratégica do Estado na economia, combinada com uma visão nacional anti-imperialista, uma política social-democrática voltada para a redução das desigualdades, e uma política ambiental voltada para a proteção da natureza.

Tornou-se usual entre cientistas políticos influentes do mundo anglo-saxão a crença que, embora não exista espaço para golpes de Estado, a democracia liberal nos países ricos está sofrendo um processo de erosão gradual, de backsliding, que levará, afinal, à sua morte. Para fundamentar essa tese, olham para o resto do mundo, vêm outros líderes populistas de direita que chegaram ao poder através de eleições e, em seguida, passam a minar o regime democrático. Não consideram que isto acontece nos países em estágio de desenvolvimento muito mais atrasados do que os países avançados, e concluem que essa é a nova forma de as democracias, até há pouco consideradas consolidadas, sofrerem um processo de erosão e terminarem. Nessa narrativa temos um inimigo e uma vítima: o inimigo é o populismo - são os líderes populistas de direita e instituições políticas ainda não suficientemente bem desenhadas -, a vítima, a democracia liberal. Qual a razão para esse populismo de direita que não está apenas nos Estados Unidos, mas também na Europa? Meu entendimento é de que se trata de uma reação, de um backlash frente à "virada neoliberal", que levou à substituição da Era de Ouro pelos Anos Neoliberais do capitalismo. Os defensores da tese do fim da democracia ignoram o neoliberalismo e a virada neoliberal, buscam uma explicação político-institucional que não se sustenta, e supõem que algumas reformas políticas e menos "austeridade" nas políticas econômicas resolverão o mal-estar que tomou conta do Ocidente. 
Esses cientistas políticos têm dificuldade em considerar a organização social maior, o capitalismo, como uma realidade histórica que engloba o regime político, e só veem a democracia liberal que, assim, deixa de ser aquilo que ela é para ser a forma de organização do próprio capitalismo. Historicamente, a democracia liberal foi a primeira forma de democracia moderna que se materializou na virada do século XIX para o $\mathrm{XX}$, quando aos direitos civis foi adicionado o direito político de todos poderem votar - o sufrágio universal. Não havia ainda o atendimento dos direitos sociais e as formas mais elaboradas de responsabilização social e participação política que hoje podemos ver nas democracias europeias mais avançadas. Surgiu no quadro de um capitalismo de empresários industriais que, naquele momento histórico - a Segunda Revolução Industrial e o surgimento das grandes corporações privadas -, estava se transformando em um capitalismo também de gerentes ou tecnoburocratas. Surgiu como uma democracia liberal, defendida pelos ideólogos liberais, que procurava limitar ao máximo o poder dos eleitores. Depois disso, não ocorreu qualquer fato histórico novo que justifique o possível fracasso desse regime político. Já o mesmo não pode ser dito do neoliberalismo uma fase reacionária e autoritária do capitalismo, que representou um retrocesso maior em relação à era dourada ocorrida no após-guerra. Não é, portanto, a democracia, mas sim o capitalismo que está em crise. Não há por que falar em fim da democracia porque, não obstante suas limitações, ela foi uma conquista da humanidade (Theborn, 1977; Przeworski, 1989). Contudo é possível se falar em crise terminal do neoliberalismo, porque foi a segunda vez que o liberalismo econômico comprovou sua incapacidade de organizar o capitalismo. Sua alternativa, que denomino desenvolvimentismo, mas também pode ser chamado de economia mista, alia uma intervenção moderada do Estado na economia a uma perspectiva nacional anti-imperialista. E após a Segunda Guerra Mundial esteve associada a uma perspectiva social-democrática, visando a redução 
da desigualdade e a proteção da natureza. Em vez de se tentar compreender o fracasso do neoliberalismo, os defensores da tese do desaparecimento gradual da democracia se concentram nas instituições políticas, quando não é nelas, e sim no papel que deve ter o Estado na vida econômica e social que está o problema. O capitalismo implicou a construção de suas duas instituições básicas - o Estado moderno e o mercado -, este constituído pelos mercados nacionais e o mercado mundial. Uma construção difícil, sujeita a crises periódicas; porém, relativamente exitosa. Surgiram, contudo, problemas novos nos anos 1970 - principalmente a concorrência dos países em desenvolvimento que passaram a exportar bens manufaturados que exigiam mudanças e adaptações. Ao contrário disso, no entanto, o que vimos foi a coalizão de classes fordista, que a Escola da Regulação estudou tão bem, por uma estreita aliança de classes financeiro-rentista, que adotou como projeto a redução dos salários diretos e indiretos dos trabalhadores.

$\mathrm{Na}$ tese do desaparecimento gradual da democracia, uma coisa é verdadeira: há um crescimento do populismo de direita não apenas em países ricos, mas também em países de renda média, como Turquia, Hungria e Polônia, onde esse espírito antidemocrático pode ser mortal para a democracia. No entanto, de onde surge esse populismo? Não é da própria democracia, mas da forma perversa e ineficiente de capitalismo que as elites econômicas liberais impuseram a seus próprios países e às demais nações dependentes. A simples denúncia do populismo não leva a nada; já compreendê-lo como consequência do fracasso do neoliberalismo pode ser esclarecedor. Fracasso em melhorar o padrão de vida e dar mais segurança para toda a população. Fracasso de um capitalismo "reformista", cujas reformas são a contrarreforma do Estado do bem-estar social. Fracasso de uma forma de organização econômica do capitalismo associada à alta instabilidade financeira, ao baixo crescimento e ao brutal aumento da desigualdade econômica. 
O problema central que enfrenta o Ocidente é definir uma nova forma histórica de capitalismo baseada em uma teoria econômica renovada, como Keynes o fez nos anos 1930, e em uma filosofia política democrática, social e ambiental. $\mathrm{O}$ aspecto político da crise do neoliberalismo foi salientado por dois fatos ocorridos em 2016 - a eleição de Donald Trump nos Estados Unidos e o referendo do Brexit no Reino Unido -, porém o que está em jogo não é o fim da democracia e, sim, a superação do neoliberalismo que, não por pura coincidência, tornou-se primeiramente dominante nesses dois países, a partir da eleição de Margaret Thatcher e Ronald Reagan. Superação não por um populismo de direita, mas por um desenvolvimentismo democrático e social.

\section{Consolidação da democracia}

Eu parto de um pressuposto geral - que o capitalismo é uma forma de organização social que se desenvolve através de fases, cada fase correspondendo a uma formação social especial. Foi o que todos os cientistas sociais aprenderam com Marx e com muitos outros pensadores que pensaram o capitalismo historicamente. Há muitas maneiras de ver essas fases, que são mais compreensíveis se as referimos a três países - o Reino Unido, a França e a Bélgica - que passaram por todas elas. Uma periodização que eu tenho usado e me parece esclarecedora. Vê, primeiro, dos séculos XVI ao XVIII, um capitalismo dos mercadores no quadro econômico do mercantilismo; segundo, no século XIX, um capitalismo dos empresários industriais, no quadro liberalismo econômico; terceiro, no século XX, um capitalismo dos gerentes, no quadro do capitalismo tecnoburocrático ou monopolista; e, finalmente, desde 1980, um capitalismo financeiro-rentista no quadro do neoliberalismo.

No plano político, as duas primeiras fases foram autoritárias, a primeira porque não garantia nem o Estado de direito, nem o sufrágio universal; a segunda, porque não 
garantia o sufrágio universal; as duas últimas são democráticas, caracterizadas pela democracia representativa ou, como é mais chamada, democracia liberal - uma expressão que é contraditória, porque é preciso não esquecer que, durante todo o século XIX, os liberais rejeitaram a democracia com o argumento que ela implicava a "ditadura da maioria". O que está em discussão na presente crise não é essa democracia, mas sim o capitalismo neoliberal. Falar na erosão da democracia sem falar no neoliberalismo é desviar a atenção do que é mais importante. A democracia progrediu nos países ricos, alcançou um pico no após-guerra, na Era Dourada do capitalismo e depois, à medida em que avançava o neoliberalismo, perdeu vigor. Colin Crouch, escrevendo em 2004, afirmou que ela se transformou em uma "pós-democracia" na medida em que continuaram havendo eleições, "mas a massa dos cidadãos representa um papel passivo, quiescente, apático" (Crouch, 2004, p. 4). Seria, no entanto, melhor dizer que se transformou em uma "democracia liberal propriamente dita” - em uma democracia neoliberal semelhante à primeira democracia, schumpeteriana, do início do século XX (Schumpeter, 1942). Uma democracia de baixa qualidade em uma forma de capitalismo regressiva; uma democracia consolidada porque representa um compromisso entre os cidadãos e as elites - os cidadãos, com expectativas rebaixadas; as elites burguesas e tecnoburocráticas, satisfeitas porque continuam a se apropriar do excedente econômico apoiadas no mercado e na sua hegemonia ideológica; satisfeitas porém preocupadas porque esse excedente cresce lentamente e a insatisfação crescente dos cidadãos com os políticos que representam os interesses dessas elites mais do que os seus.

O segundo pressuposto diz respeito ao problema da consolidação das democracias - um tema que concentrou a atenção dos cientistas políticos após a terceira onda de democratizações a partir de meados dos anos 1970 (Linz e Stepan, 1996 Schedler, 1998). Linz e Stepan afirmam 
que "por 'democracia consolidada', nós entendemos um regime político no qual a democracia, como um sistema complexo de instituições, regras e padrões de incentivos e desincentivos, se tornou, numa frase, the only game in town" (Linz e Stepan, 1996, p. 15, tradução nossa). Muitas novas democracias, como a espanhola ou a brasileira, nasceram consolidadas, enquanto outras emergiram em países subdesenvolvidos, que não haviam ainda realizado sua revolução industrial e capitalista. Nesses casos, nos quais a democracia foi geralmente instalada por pressão externa, ela se mantém instável. Em um trabalho sempre citado, Seymour Lipset (1959) mostrou que existe uma forte correlação entre o nível de desenvolvimento econômico de um país e o fato de ser democrático ou não. Depois muitos estudos confirmaram esse achado, mas como observaram Rueschemeyer, Huber e Stephens (1992), em um excelente livro, Capitalist Development $\mathcal{E}$ Democracy, após realizarem um grande survey da literatura sobre a relação entre o desenvolvimento econômico e a democracia, não encontram uma explicação satisfatória para o problema, que continuava uma "caixa preta".

Na primeira versão de meu paper "Transição, consolidação democrática e revolução capitalista” (Bresser-Pereira, 2011), elaborado em 2002 e publicado somente em 2011, eu creio que encontrei uma explicação estrutural para a consolidação democrática. Minha questão foi: por que a democracia só passou a ser o regime político preferido e consolidado no século XX? E a resposta histórico-estrutural que encontrei foi que a democracia era impossível nos modos de produção anteriores ao capitalismo, nos quais a apropriação do excedente econômico pela classe dominante era realizada por meio do controle direto do Estado. Com a formação do estado-nação e a Revolução Industrial, inicialmente no Reino Unido no início do século XIX, completou-se a "revolução capitalista"; assim, a apropriação do excedente econômico pôde ser realizada no mercado através da troca de valores 
"equivalentes", o que permitiu que a burguesia realizasse lucros independentemente do Estado. Bastava agora que o Estado garantisse a propriedade e os contratos. A burguesia, apoiava a garantia dos direitos civis e o Estado de direito, porém continuava a vetar a democracia porque temia o sufrágio universal (o segundo elemento do conceito mínimo de democracia) que poderia levar à eleição de partidos socialistas que a expropriassem. Entretanto, os partidos socialistas quando chegavam ao poder não implantavam o socialismo e a burguesia, que tinha o controle da mídia, podia financiar e tornar dependentes os políticos. Desse modo, a partir de uma série de dispositivos constitucionais que limitara o poder dos parlamentos e do poder executivo, a burguesia e os ideólogos liberais perderam o medo do sufrágio universal, suspenderam o veto à democracia, e a transição democrática se completou. A classe capitalista foi assim a primeira classe social dominante a levantar seu veto à democracia porque foi a primeira 60 a não depender da violência do Estado para se tornar e se manter rica. Surgiu, então, um segundo argumento para a classe capitalista apoiar a democracia. Diferentemente das classes dominantes anteriores, que eram pouco mais do que uma oligarquia, ela é uma classe social muito grande, que precisa de mecanismos institucionais para seus membros buscarem poder político. A democracia revelou ser esse mecanismo institucional e vimos, em muitos países, um partido liberal e um partido conservador, ambos rigorosamente burgueses, se alternarem no poder.

A história política dos países mais avançados mostra a solidez da democracia naqueles que já completaram sua revolução capitalista. Países que não atendem a essa condição podem se tornar democráticos em decorrência da pressão de países mais poderosos ou por imitação institucional. No entanto, a democracia nesses países é sempre instável. No caso dos países ricos, porém, a democracia se mostra capaz a sobreviver, não obstante crises de vários tipos. 
A exceção sempre lembrada seria a da Alemanha de Hitler, mas essa não é um verdadeiro desvio, porque a primeira experiência de democracia na Alemanha, a República de Weimar, foi antes uma experiência de crise permanente em um quadro de ressentimento pela derrota na guerra. Além do fato óbvio de que em nenhum país desenvolvido que se tornou democrático a democracia morreu, temos a comprovação empírica da tese da consolidação estrutural deste regime de governo na grande pesquisa que Adam Przeworski e associados realizaram no livro Democracy and Development (Przeworski, Alvarez, Cheibub e Limongi, 2000). Nessa pesquisa sobre a democracia, que envolveu o estudo das mudanças de regime político de 141 países no período 1950-1990, seus autores concluíram que depois que a democracia passa a caracterizar um país desenvolvido, ela perdurará por tempo indefinido. Ou, como ouvi Przeworski dizer mais de uma vez em conferências, quando um país já é democrático e tinha uma renda per capita superior a US\$ 6.000 em 1990, a probabilidade que ele volte a ser autoritário é zero. Ora, um país com essa renda por habitante, que a preços de hoje, considerada a inflação nos Estados Unidos, corresponde a US\$12.220, certamente já terá completado sua revolução capitalista e sua democracia está, portanto, consolidada - a não ser que seja um país exportador de petróleo ou de diamantes. Em um trabalho mais recente, Przeworski encontra novo dado que confirma essa tese. Estudando os regimes políticos até 2014, concluiu que a renda per capita média dos países cuja democracia sobreviveu antes de 2008 foi US $\$ 18.012$, enquanto naqueles países em que a democracia entrou em colapso essa média foi de apenas US\$ 5.770 (Przeworski, 2019, p. 34).

Uma outra forma de considerar a consolidação da democracia nos países ricos é usando o método de análise histórica da democracia desenvolvida por Charles Tilly no livro de 2007, Democracy. Nesse livro, esse notável sociólogo e cientista 
político define democracia não em termos discretos, como a maioria dos cientistas políticos faz, mas em termos de gradação. "Um regime é democrático na medida em que as relações entre o Estado e os cidadãos apresentam consulta igual, protegida e mutuamente obrigatória" (Tilly, 2007, p. 58). Quando há democratização, essa consulta aumenta e se torna mais obrigatória, o inverso ocorrendo na "desdemocratização”. O processo de democratização envolve mudanças em três áreas: nas relações de confiança, no caráter categórico da desigualdade e nos centros autônomos de poder. As redes de confiança entre os cidadãos envolvem um grande e ramificado número de relações interpessoais por meio das quais eles definem seus valores, recursos e suas experiências de êxitos ou fracassos. A desigualdade categórica é definida pelas fronteiras estabelecidas entre grandes grupos de pessoas que têm oportunidades de vida muito diferentes devido a gênero, raça, etnia, nacionalidade e religião. Os processos de equali62 zação dependem diretamente da diminuição dessa diferença categórica. Finalmente, os centros autônomos de poder existentes fora do Estado incluem as relações interpessoais e envolvem a defesa ou a alteração da distribuição de recursos. Nessas três áreas os processos e as mudanças ocorrem de forma lenta e não-linear. Dialética, eu diria. Não é de um dia para o outro que as redes de confiança se estabelecem, as diferenças categóricas são amainadas, e a influência dos centros autônomos é razoavelmente tornada transparente e limitada. Para desenvolver esses conceitos, Tilly estudou longamente a história da democracia e, principalmente, da França e da "incrível" Suíça. E concluiu que os processos de democratização, ao qual ele dá muito mais atenção do que ao processo de "desdemocratização", são processos de longa duração. Existe a possibilidade da "desdemocratização"

se o país destrói seus arranjos distributivos e equalizadores que foram construídos no capitalismo democrático, 
se os ricos desligam suas redes de confiança da política e constroem comunidades fechadas e escolas privadas, podemos esperar que um processo de desdemocratização ocorra (Tilly, 2007, p. 204, tradução nossa).

Sem dúvida. Mas como foi lento e difícil construir as redes de confiança, tão lento quanto será sua destruição, e custa acreditar que sociedades minimamente racionais farão tal coisa. Processos semelhantes a esta caracterização de Tilly têm ocorrido nos Estados Unidos, mas eles não se sustentam.

Milan Svolik (2008), estudando especificamente o problema da consolidação da democracia, distinguiu as democracias consolidadas das que meramente sobrevivem, as quais ele chamou de "democracias transicionais". As variáveis que determinam se uma democracia está consolidada são o nível de crescimento econômico do país, a taxa de crescimento, o fato de o país ter um regime presidencialista ou parlamentarista, e o tipo de experiência autoritária do país. Quanto mais rico o país for, mais consolidada será sua democracia. O nível de desenvolvimento econômico é a variável fundamental. A ela o pesquisador adicionou duas variáveis institucionais: se o país adota presidencialismo ou parlamentarismo e a presença ou a ausência de regime militar em sua história democrática. Assim, o autor concluiu que os países presidencialistas e os países que foram governados por regimes militares enfrentam uma probabilidade maior de colapso do que os países parlamentaristas e que não tiveram governo militar. Essas variáveis, porém, são relevantes apenas no caso das democracias transicionais. Mais recentemente, Iversen e Soskice (2019, p. 258, tradução nossa), que reconheceram a resiliência das democracias consolidadas, ofereceram como explicação para esse fato: "a democracia prospera no capitalismo avançado porque as classes médias são recompensadas com educação, bons empregos e mobilidade para cima”. É uma visão do capitalismo que Przeworski 
introduziu quando, em Capitalismo e social-democracia (1989), mostrou que seria racional para os trabalhadores empregados e com salários crescentes rejeitarem o socialismo. Isto não significa que esteja abolida a luta de classes, entretanto ajuda a explicar não apenas por que não houve revolução socialista, mas também porque as democracias nos países ricos já duram mais de cem anos. Além disso, torna absurda a tese da morte aos poucos da democracia em democracias avançadas, assim como compará-las com os regimes políticos de países em estágio muito menos avançado de desenvolvimento e sem uma experiência histórica de democracia.

\section{Instituições democráticas ou organização da produção?}

A democracia está consolidada, porém parece certo de que as coisas não estão caminhando bem no Ocidente, mesmo se deixada de lado a pandemia causada pela Covid19. Não estão bem no plano político, no qual vemos partidos conservadores tradicionais passarem a apoiar líderes populistas de direita e eles serem eleitos não obstante a irracionalidade de seu comportamento. E não estão bem no plano econômico: os Estados Unidos continuam a crescer, mas de maneira muito modesta, enquanto o resto do Ocidente está quase estagnado desde 2008; uma “estagnação secular' se configura, definida por taxas de juros muito baixas e ampla emissão de moeda pelos governos dos países ricos e que, no entanto, não encorajam as empresas a investir; as taxas de lucro são satisfatórias para as grandes empresas, apesar disso igualmente não as estimulam a investir, pois elas não emergem de uma demanda sustentada para as corporações, mas de um incansável processo de fusões e aquisições que visam construir monopólios e aumentar as margens de lucro.

A questão é saber onde está o problema. A explicação que nos oferece o pensamento hegemônico no Ocidente é que a crise é da democracia liberal e a sua causa é o populismo de direita. Eu estou afirmando que a crise não é uma 
crise da democracia desvirtuada pelo populismo, porque este é apenas mais um sintoma político principal da crise. A crise hoje em curso no capitalismo não é uma crise de regime político e sim da forma que o capitalismo assumiu a partir de 1980 - a forma neoliberal e financeiro-rentista e que sua causa é a incapacidade desse neoliberalismo de organizar o capitalismo de maneira razoavelmente eficiente, razoavelmente estável e razoavelmente menos injusta. Afirmo isto pensando no Ocidente rico e nos países de renda média como o Brasil, que embarcaram igualmente no neoliberalismo e estão sofrendo as suas consequências. Excluo os países do Leste da Ásia e do Sudeste da Ásia, onde seus Estados, não obstante as concessões que foram obrigados a fazer à nova verdade imperial, se mantiveram basicamente desenvolvimentistas e vêm crescendo mais depressa que o Ocidente e excluo principalmente a China, que já se transformou no país com o maior PIB do mundo, medido de acordo com a paridade do poder de compra, e hoje compete em condições de igualdade com os Estados Unidos - uma coisa que há apenas dez anos atrás era inimaginável. Em consequência desse caminho essencialmente equivocado adotado pelo Ocidente, que reduziu o papel econômico do Estado e demandou do mercado resultados que ele não pode produzir, o eixo econômico do mundo está se transferindo do Norte do Atlântico para o Oriente. Nesse quadro de competição entre os Estados Unidos e a China, no qual o país desafiante continua dominado pelo autoritarismo mas exibe uma forma desenvolvimentista de organização econômica claramente mais eficiente, os defensores da democracia e dos direitos civis no Ocidente são obrigados a ouvir dos dirigentes chineses seu discurso agora mais ambicioso, que fala sobre "a superioridade da solução chinesa” também no plano político.

A crise do capitalismo neoliberal não é uma mera crise econômica; é também política, social e ambiental. Logo, se o capitalismo está em crise, o respectivo regime democrático não pode estar vivendo seus melhores dias. Está ameaçado. 
Porém, para enfrentar essa ameaça a solução não está em reformar as instituições políticas e sim em rever as principais instituições que organizam o capitalismo contemporâneo - principalmente a forma pela qual o Estado intervém no sistema econômico. Para avaliar essas duas explicações alternativas, devemos nos perguntar quais as instituições que se deterioraram. Foram acontecimentos que ocorreram na relação do mundo rico com o resto do mundo? A nova competição representada pelos países asiáticos? O aumento do número de imigrantes e exilados políticos procurando entrar nos países ricos e a reação dos trabalhadores brancos a isto? Ou os problemas foram políticos? Surgiram em instituições como a democracia representativa, o sufrágio universal, o presidencialismo, o parlamentarismo, o sistema eleitoral distrital majoritário ou o sistema proporcional por listas fechadas? ${ }^{2}$ Nos partidos políticos? Ou foram mudanças no sistema tributário, nos recursos destinados ao Estado do bem-estar social, na legislação trabalhista? 66 Ou resultaram de mudanças no sistema cultural, principalmente no avanço do individualismo possessivo de que nos falava Macpherson (1962)? Ou, no plano da sociedade, o problema maior foi a perda de coesão social? Ou o problema econômico é estrutural; decorre da crescente relação capital-produto e queda da produtividade do capital, de forma que a taxa de lucro só está sendo garantida devido à repressão salarial, à concessão de crédito às famílias acima de sua capacidade de pagamento e devido ao aumento do poder monopolista das grandes corporações que aumentam gradualmente suas margens de lucro? Ou, no plano da política econômica, ela deixou de garantir que os cinco preços macroeconômicos ficassem no lugar certo? A taxa de juros caiu demais? Os governos perderam determinação de controlar os fluxos de capital? Ou de realizar poupança pública para financiar o investimento público?

\footnotetext{
2 Não se considerando, naturalmente, o monstrengo que é o sistema brasileiro de eleições proporcionais com listas abertas.
} 
Em outras palavras, vemos que o capitalismo enfrenta hoje uma crise profunda, que tenho procurado discutir sob seus diversos aspectos através da teoria novo-desenvolvimentista. Uma crise que os analistas políticos da morte gradual da democracia, impactados pela eleição em 2016 para a presidência dos Estados Unidos de um líder político que não é um simples populista de direita, mas uma figura em contradição com tudo o que aprendemos considerar civilizado e digno nas sociedades modernas, entenderam ser apenas uma crise política quando é muito mais do que isso.

\section{A tese da morte gradual}

Vejamos agora, brevemente, o que diz a tese da morte da democracia aos poucos. Começo pelo livro de Levitsky e Ziblatt, distinguidos cientistas políticos da Universidade de Harvard, Como as democracias morrem (2018). Os dois autores começam confirmando a ligação do seu livro a Trump. Antes da sua eleição, dizem eles, nunca pensaríamos que a democracia americana pudesse estar em perigo, mas, agora, "os políticos norte-americanos tratam seus rivais como inimigos, intimidam a imprensa livre e ameaçam rejeitar os resultados das eleições" (Levitsky e Ziblatt, 2018, p. 13). Ainda na introdução, mostram sua preocupação com um problema maior, o da perda de coesão da sociedade americana - porém, em seguida voltam-se para o regime político: "se uma coisa é clara ao estudarmos os colapsos ao longo da história, é que a polarização extrema pode matar a democracia" (Levitsky e Ziblatt, 2018, p. 20). Estaria, então, a democracia americana ameaçada por um golpe militar e pela subida ao poder de um ditador? Não, não é isso que temem. O que eles temem são políticos originalmente eleitos, mas que se revelam autoritários e vão, pouco a pouco, subvertendo a democracia e, afinal, a mantando. E trazem a história para confirmar sua preocupação: Mussolini, na Itália; Hitler, na Alemanha; Alberto Fujimori, no Peru. Ou na história presente, Recep Erdogan na Turquia, 
Nicolás Maduro, na Venezuela, Viktor Orban na Hungria. E concluem: "[a]o capturar os árbitros, comprando e enfraquecendo oponentes e reescrevendo as regras do jogo, líderes eleitos podem estabelecer uma vantagem decisiva - e permanente - sobre seus oponentes" (Levitsky e Ziblatt, 2018, p. 94). Por que essa morte da democracia? Para responder a essa questão, os dois autores se concentram nos Estados Unidos e em uma questão estritamente política. Dizem eles que em seu país os partidos políticos e seus experientes líderes foram sempre os guardiões da democracia. Primeiro, os políticos, depois, os partidos, no quadro institucional do Colégio Eleitoral, escolhiam candidatos razoáveis de maneira prudente. As eleições primárias acabaram com esse sistema, principalmente a partir de 1972, quando elas se tornaram vinculantes, e, assim, "os partidos políticos afrouxaram de maneira substancial o controle dos seus líderes sobre o processo de escolha de candidatos" (Levitsky e Ziblatt, 2018, p. 57).

A argumentação de Levitsky e Ziblatt é duplamente pouco convincente. Primeiro, em relação às "evidências" que apresentam para a morte gradual da democracia nos países ricos. Que relação tem a subida ao poder de Trump com a de Mussolini e Hitler? São experiências históricas completamente diferentes. Quando os dois ditadores chegaram ao poder, não havia ainda uma experiência de democracia na Itália e a experiência alemã era mínima. Os dois países estavam inconformados pelo fato de, ao se industrializarem de forma tardia, não conseguiram conquistar tantas colônias quanto o Reino Unido e a França, e ressentidos pela derrota recente na Primeira Guerra Mundial. A mesma pergunta cabe em relação a dirigentes atuais como Erdogan, Orban e Putin, que governam países que sem experiência de democracia, estão em estágio de desenvolvimento econômico atrasado em relação aos países ricos, seus dirigentes não são estritamente ditadores mas têm personalidade forte e autoritária, praticam políticas que estão na fronteira entre o democrático e o autoritário, 
e adotam um nacionalismo econômico não aceitável para os Estados Unidos. É razoável, portanto, que a democracia nesses países não esteja consolidada. Já a experiência de democracia dos norte-americanos é longa e rica, como também é a experiência democrática do outro grande país ocidental tomado pelo populismo de direita - o Reino Unido.

Um segundo livro, também publicado em 2018 e tendo também como autor um professor de Harvard, Yascha Mounk, discute a crise da democracia liberal a partir da chegada ao poder de um populista de direita nos Estados Unidos. Diz-nos ele,

os cidadãos se desiludiram completamente com a política e se tornaram irrequietos, encolerizados, e mesmo desdenhosos [...] não pode haver mais qualquer dúvida que nós estamos passando por um momento populista. A questão é saber se esse momento populista se transformará em uma era populista; ele põe em dúvida a sobrevivência da democracia liberal (Mounk, 2018, p. 2, tradução nossa).

O problema, portanto, está no populismo tomando conta da casa americana. Mas não apenas no populismo; para ele a democracia está em processo de "desconsolidação" (Mounk, 2018). Nos Estados Unidos, nos anos 1930 e 1950 respectivamente, $71 \%$ e $57 \%$ dos americanos gostavam de viver em uma democracia, contra apenas $29 \%$ nos anos 1980. O interesse dos americanos pela política caiu de maneira ainda mais acentuada. A confiança no Congresso americano caiu de $40 \%$ nos anos 1970 para 7\% em 2014; hoje, dois terços dos cidadãos americanos consideram importante viver em uma democracia, mas apenas um terço dos millennials (nascidos entre, aproximadamente, 1980 e 1990) têm a mesma opinião. Mounk diz que "a democracia liberal é todas as coisas para todos: a promessa para as massas que elas poderão tomar decisões; a promessa às minorias que elas serão protegidas de maiorias opressivas; 
e a promessa às elites econômicas que elas conservarão suas riquezas" (Mounk, 2018, p. 54). Isto, para um regime político, é prometer demais. E se torna impossível no quadro do capitalismo neoliberal. O liberalismo político foi sempre contra a democracia, apenas a tendo aceitado quando ficou claro que os capitalistas não seriam expropriados. Por outro lado, como forma econômica de organização do capitalismo, o liberalismo econômico é inferior ao desenvolvimentismo. Mounk, porém, é menos ambicioso. Para ele, basta tomar medidas que consertem a economia: impostos mais progressivos, reduzir o preço das habitações; voltar a elevar a taxa de produtividade estagnada desde os anos 1980; recuperar o significado do trabalho como fonte de identidade (Mounk, 2018, tradução nossa). Vimos que Linz e Stepan afirmaram que uma democracia se torna consolidada quando ela se transforma "no único jogo a ser considerado". Mounk conclui, pessimista: "a evidência altamente preocupante é que em muitos países no mundo, 70 dos Estados Unidos ao Reino Unido, e da Austrália à Suécia, a democracia não parece mais ser the only game in town" (Mounk, 2018, p. 123 tradução nossa).

Vejamos agora o livro de David Runciman, também com um título sugestivo, Como a democracia chega ao fim. Foi também publicado em 2018 e seu autor é professor da Universidade de Cambridge. As ideias são semelhantes, e foram também escritas sob o impacto da eleição de Trump, porém elas são menos pessimistas. "A democracia dos Estados Unidos não está intimidada, nem é desatenta ao ponto de permitir que Trump permaneça no cargo além de 2025. E é muito pouco provável que chegue mesmo a essa data" (Runciman, 2018, p. 228). Runciman reconhece que existem democracias antigas e estáveis e observa que "as democracias fortes são praticamente imunes a ataques frontais porque suas instituições são resistentes. Em consequência os ataques às democracias estáveis costumam vir pelos flancos" (Runciman, 2018, p. 66). E, ao contrário do que acontece nos golpes de Estado 
nas democracias fracas, os resultados desses ataques não são claros. "Não existe um antes e um depois. Só o espaço envolto em sombras entre um e outro" (Runciman, 2018, p. 67). Assim, embora o título do livro nos prometa contar como as democracias chegam ao fim, ficamos sem sabê-lo. Sabemos apenas que "a democracia não está funcionando bem - se estivesse não teríamos esse retrocesso populista" (Runciman, 2018, p. 80). Sem dúvida, o populismo que foi ignorado por Levitsky e Ziblatt, foi lembrado por Mounk e Runciman. Mas os três autores, obedientes às normas da academia, ficam presos às suas especialidades. Buscando causas nas instituições políticas quando elas não estão aí.

Finalmente, o último livro de Adam Przeworski, The Crisis of Democracy (2019), no qual ele também está preocupado com a democracia americana e fala em erosão gradual da democracia em outros países menos desenvolvidos como a Turquia, a Polônia e a Hungria. O autor faz um excelente resumo dos dados, mostrando a perda de apoio popular para a democracia e elabora um survey da discussão sobre esse tema. Przeworski afirma que a democracia está sendo minada "furtivamente" [by stealth], mas conclui rejeitando a ideia de que a democracia esteja morrendo ao rejeitar a ideia de que este seja o principal problema:

Eu não creio que a sobrevivência da democracia na maioria dos países esteja realmente sendo posta em dúvida, mas não sei o que nos tirará do presente descontentamento. Ele não pode ser aliviado por acontecimentos políticos contingentes como os resultados de eleições no futuro. Esta crise não é apenas política; ela tem profundas raízes na economia e na sociedade. (Przeworski, 2019, p. 206, tradução nossa)

De acordo. Apenas especificaria que essa crise, que tem "raízes na economia e na sociedade", é a crise da própria formação social, é a crise do capitalismo neoliberal. Para Przeworski, 
as causas da insatisfação generalizada com a democracia e com os políticos estão em fatos inerentes à democracia como: os eleitores não terem muitas alternativas nas eleições; as propostas dos partidos políticos e dos candidatos com possibilidade de vitória serem relativamente semelhantes; na eleição, a pessoa sentir quão pouco eficaz é seu voto em meio a tantos outros; e as políticas adotadas pelo governo eleito e mais amplamente pelo Estado não serem aquelas com as quais concordamos, ainda que nosso candidato tenha vencido as última eleições. Por isso, Przeworski vê a insatisfação com a democracia como um processo recorrente e inevitável. Mas

essas características gerais da democracia não explicam a presente popularidade da retórica populista "anti-elite", "anti-establishment", "antissistema", como também não explicam o caráter inerentemente elitista da democracia liberal adotada pelos founding fathers dos Estados Unidos, para os quais "o papel das eleições era ratificar a posição daqueles com direito de governar por sua posição econômica e social" (Przeworski, 2019, p. 200, tradução nossa).

\section{0 problema do populismo}

O inimigo para a análise da morte aos poucos da democracia liberal é o populismo de direita. Essa também é a visão de Norris e Inglehart em seu livro Cultural Backlash (2019). O capitalismo neoliberal, que eu entendo ter sido o originador desse populismo, também está ausente. Há uma reação populista nos Estados Unidos e na Europa Ocidental, mas esse backlash é explicado pelo fato de que, no após-guerra, a crescente prosperidade, o maior acesso à educação universitária e a maior igualdade de gênero representou "uma revolução silenciosa de valores socialmente liberais e pós-materialistas" (Norris e Inglehart, 2019, p. 15-16, tradução nossa) que, como seria de se esperar, causou uma reação 
conservadora da "geração entreguerras de brancos europeus, sem educação universitária, mais religiosos, homens, e residentes em comunidades rurais" (Norris e Inglehart, 2019, p. 15-16, tradução nossa).

Essa é uma ideia curiosa, que naturalmente satisfaz os defensores da "democracia liberal" que passam agora a representar os grandes avanços comportamentais ocorridos no século XX, principalmente na era de ouro do capitalismo. Realmente, embora as mulheres continuem a ser descriminadas, elas experimentaram um grande avanço, o que também ocorreu em relação ao aborto, aos homossexuais e aos transexuais, que passaram a ser mais respeitados. E, de fato, o neoliberalismo, tão violento com os trabalhadores e os pobres, porque seu objetivo maior foi sempre a redução de salários reais diretos e indiretos, aceitou sem muita resistência essas mudanças comportamentais. Foi isto que levou Nancy Fraser (2017) a fazer a crítica do "neoliberalismo progressista" - o neoliberalismo dos modernos, dos bons e belos, de Hillary e Bill Clinton, do The Economist, fundamentalista de mercado, associado ao capitalismo financeiro-rentista, mas aberto para as inovações econômicas e sociais.

Da mesma forma que se publicaram muitos livros sobre o fim da democracia nos anos recentes (Judis, 2016; Monedero, 2017; Finchelstein, 2019), publicaram-se também inúmeros livros sobre o populismo, dos quais este de Norris e Inglehart e o de Roger Eatwell e Mathew Goodwin, National Populism: the revolt against liberal democracy (2018) são os mais relevantes. Neste livro, o populismo de direita é descrito como uma reação contra dois choques, o da grande recessão e o do grande aumento dos refugiados emigrando para os países ricos. A grande recessão que se seguiu à crise de 2008 foi a crise do capitalismo neoliberal. Sua análise é interessante, porque os dois autores insistem em rejeitar as críticas de que esse populismo seja fascista ou racista. Para eles, 
os fatores que abriram o caminho para o populismo nacional estão profundamente entranhados no tecido das nossas nações. Eles têm como raízes as contradições entre o funcionamento da democracia no nível nacional e um mercado crescentemente global, em uma profunda tradição das elites de suspeitar as massas, um sentimento nacionalista latente bastante difundido e na erosão das relações entre os cidadãos e os partidos políticos (Eatwell e Goodwin, 2018, p. 270, tradução nossa).

Nem todos esses problemas são exclusivos do neoliberalismo, mas nele eles se aprofundaram. Não é razoável esperar que os americanos prejudicados com a política de abertura econômica radical dos Estados Unidos em relação à China não ouçam candidatos populistas que prometem mudar essa política.

Como enfrentar essa ameaça? Para Levitsky e Ziblatt 74 (2018), Mounk (2018) e Runciman (2018), o populismo é uma distorção acidental da democracia liberal. Logo, é preciso defender o liberalismo econômico, mostrar suas qualidades insuperáveis... É preciso também diminuir a desigualdade, tornando os impostos novamente progressivos, construir mais habitações e aumentar a produtividade. Mounk se preocupa com a quase-estagnação, no entanto em relação ao aumento da produtividade ou ao desenvolvimento econômico, ele reconhece que "não está claro como lográ-lo" (Mounk, 2018, p. 227, tradução nossa). Claramente, não está no seu horizonte cognitivo criticar o liberalismo econômico radical que tomou conta do mundo rico. Como os demais progressistas, ele quer transformar os Estados Unidos em uma social-democracia como a europeia, porém não compreende que a social-democracia da era dourada do capitalismo era no plano econômico desenvolvimentista ao invés de liberal; caracterizava-se por uma intervenção moderada mas efetiva no setores 
não-competitivos da economia e no esforço para administrar os cinco preços macroeconômicos e não apenas a inflação. Norris e Inglehart (2019) não têm soluções, pois em sua visão o problema não é nem econômico, nem político, mas cultural; ele está na inconformidade dos conservadores com o "liberalismo social" das elites. Przeworski é mais realista. Ele não crê que baste atacar o "populismo". A palavra "populismo" só começou a ser usada a partir do final do século XIX, mas, antes disto, dada a diferença entre os governados e os governantes, as elites econômicas identificadas com os que governam sempre encontraram forma de desqualificar os políticos populares e, assim, desqualificar o próprio povo.

Eu fico muito incomodado com a forma que o conceito de populismo político tem sido usado pelo establishment neoliberal. Há um populismo de direita, que no momento está assombrando o Ocidente, mas esse establishment não esquece do populismo de esquerda, o populismo, por exemplo, de Bernie Sanders, várias vezes citado nesses trabalhos que estou criticando. Ora, Bernie Sanders, em suas campanhas políticas, não dizia que falava em nome do "povo" nem punha toda a culpa dos problemas nacionais nos "políticos" ou nos "estrangeiros" - as características que definem o populismo. Não posso, portanto, deixar de suspeitar que a palavra "populismo" é amplamente abusada pelo establishment neoliberal em crise. Tudo o que não estiver basicamente de acordo com sua visão de mundo - tudo o que não fizer parte da visão de mundo dos economistas de Chicago e de Harvard, de Oxford e de Cambridge, é populista e mau. Não é hora, aqui, para uma discussão mais profunda do populismo, porém uma coisa é certa: em seu nome já ocorreram tanto grandes avanços como grandes retrocessos.

\section{Conclusão}

O colapso do estatismo na União Soviética em 1991 e a crise das esquerdas em todo o mundo explicam por que 
o liberalismo econômico foi considerado vitorioso e, nos Estados Unidos mais do que na Europa, a democracia tenha voltado a ser chamada com insistência de "democracia liberal". Os vitoriosos não perceberam que o derrotado com o colapso da União Soviética, assim como o abandonado pelos chineses em 1979, não foi o socialismo, que era impossível, mas o estatismo, que era ineficiente. A democracia liberal não é a "melhor" forma de democracia, e sim uma forma de democracia mínima, compatível com um Estado mínimo e com o capitalismo neoliberal. A democracia liberal não é a democracia desejada pelo povo, mas sim por uma elite neoliberal financeiro-rentista e por uma classe média conservadora, que no passado rejeitaram a democracia ao rejeitar o sufrágio universal e hoje, na prática, rejeitam a melhoria da qualidade da democracia ao procurar limitar ao máximo os poderes do governo e a autonomia dos políticos. Nos Estados Unidos, onde as elites econômicas "compram" os políticos ao financiar suas campanhas eleitorais - pois, não existe ali um financiamento público de campanhas -, a democracia muitas vezes se confunde com uma plutocracia; só não se confunde plenamente porque cidadãos com espírito público organizaram financiamento popular para candidatos progressistas, como Barack Obama.

Os eleitores muitas vezes parecem desinteressados pela política, mas hoje, nos países ricos, eles são mais exigentes do que eram há um século; eles sabem o que foi o progresso econômico e social e se desapontaram com os políticos que se submeteram aos economistas e às elites econômicas neoliberais. Manifestam, assim, sua insatisfação com a democracia liberal. Não podem mostrar sua inconformidade com o neoliberalismo porque este conceito não faz parte dos conceitos admitidos pelo establishment, veiculados pela mídia e adotados nas pesquisas políticas; por isso, a ideia de neoliberalismo não faz parte do repertório popular. 
A crise do capitalismo não tem apenas uma dimensão econômica, mas também política e ideológica. O que está em jogo não é apenas a democracia. Por isso, é um equívoco falar em morte da democracia. O que está em jogo é muito mais. É o crescimento próximo de zero da renda por habitante, a estagnação dos baixos salários desde os anos 1980, o retorno da instabilidade econômica superada na era dourada do capitalismo, o contínuo aumento da desigualdade econômica que ocorre desde então, o aumento do poder de monopólio das grandes empresas por meio de fusões e aquisições e a falta de demanda que estimule as empresas a investir. O que está em jogo é o domínio de uma coalizão financeiro-rentista e tecnoburocrática estreita que substituiu a ampla coalizão fordista. É as pessoas que se viram presas a uma roda viva, a uma competição de todos contra todos e que as torna profundamente inseguras. É esse mundo implacável de ganhadores e perdedores, no qual os perdedores não são apenas os pobres, mas também a baixa classe média de trabalhadores brancos, que, angustiados e inconformados, culpam a imigração por seus males e recorreram ao populismo para fazer frente ao problema e que não compreendem que os partidos e os populistas de direita atacam seu emprego e seus salários diretos e indiretos tão agressivamente quanto o faz o liberalismo econômico em crise. É esse individualismo sem limites em que se transformou o liberalismo político desde que ele deixou de ser moderado tanto pelo socialismo popular quanto pelo republicanismo. O que está em jogo é tudo isso somado.

Nesse quadro dominado pelo individualismo, pela riqueza de poucos e pela pobreza de muitos, as sociedades ricas tornaram-se heterogêneas, as identidades ganharam relevância, e o nacionalismo étnico voltou a assombrar e pôr em risco a tolerância e a democracia. E mostrou ainda mais claramente um fato econômico e outro político. Nenhuma sociedade pode ser sadia se for excessivamente desigual, se nela não houver um razoável grau de compromisso de um número importante de cidadãos com a 
solidariedade e o interesse público, e se não houver uma dialética viva entre valores sociais e republicanos e o interesse próprio. No quadro de um liberalismo individualista, os valores morais e os princípios de convivência social perderam relevância, os cidadãos, os servidores públicos e os políticos passaram a ser vistos como indivíduos que se preocupam apenas com seus próprios interesses, e a possibilidade da existência de cidadãos e de políticos solidários e republicanos foi excluída. Eles, porém, existem e, no quadro da competição capitalista, sabem que é necessário defender os mais fracos, aqueles que não têm condições de competir. Eles existem e são essenciais para a construção de uma boa sociedade. Uma sociedade moderna, que não logra enfrentar o problema da desigualdade, nem conta com cidadãos e políticos republicanos, caminha para a barbárie.

\section{Luiz Carlos Bresser-Pereira}

Professor emérito da FGV e membro da Comissão Arns. É doutor honoris causa pela Universidade de Buenos Aires e livre-docente em Economia pela USP. Foi ministro da Fazenda (1987). Nos últimos 20 anos desenvolveu a Teoria Novo-Desenvolvimentista, cuja economia política está voltada para o capitalismo e o Estado, e a macroeconomia, para o desenvolvimento e contas externas.

\section{Bibliografia}

Avritzer, Leonardo. 2019. O pêndulo da democracia. São Paulo: Todavia.

Bresser-Pereira, Luiz Carlos. 2011. Transição, consolidação democrática e revolução capitalista. Dados, 2011, v. 54, n. 2, pp. 223-258.

Crouch, Colin. 2004. Post-democracy. Cambridge: Polity Press.

Eatwell, Roger; Goodwin, Matthew. 2018. National Populism: the revolt against liberal democracy. London: Pelican Books.

Finchelstein, Federico. 2017. From fascism to populism in history. Oakland: University of California Press.

Fraser, Nancy. 2017. Progressive neoliberalism versus reactionary populism: a Hobson's choice. In: Geiselberger, Heinrich (ed.). The Great Regression. Cambridge: Polity Press. pp. 40-48. 
Iversen, Torben; Soskice, David. 2019. Democracy and prosperity: reinventing capitalism through a turbulent century. Princeton: Princeton University Press.

Judis, John. 2016. The Populist Explosion: how the great recession transformed american and european politics. New York: Columbia Global Reports.

Levitsky, Steven; Ziblatt, Daniel. 2018. Como as democracias morrem. Rio de Janeiro: Zahar.

Linz, Juan; Stepan, Alfred. 1996. Toward consolidated democracies In: Diamond, Larry; Plattner, Marc; Chu, Yun-han; Tien, Hung-mao (org.). Consolidating the third wave democracies. Baltimore: The John Hopkins University Press. pp. 14-33.

Lipset, Seymour. 1959. Some Social Requisites of Democracy: Economic Development and Political Legitimacy. American Political Science Review, v. 53, n. 1, pp. 69-105.

Macpherson, Crawford. 1979. A teoria política do individualismo possessivo. São Paulo: Paz e Terra.

Monedero, Juan Carlos. 2017. La democracia agredida: populismo, pos-democracia y neoliberalismo. Nueva Sociedad, n. 267, pp. 142-155.

Mounk, Yascha. 2018. The People vs. Democracy: why our freedom is in danger $\mathcal{E}$ how to save it. Cambridge: Harvard University Press.

Norris, Pippa; Inglehart, Ronald. 2019. Cultural backlash: Trump, Brexit, and authoritarian Populism. Cambridge: Cambridge University Press.

Przeworski, Adam. 1989. Capitalismo e social-democracia. São Paulo: Companhia das Letras.

Przeworski, Adam. 2019. Crises of Democracy. New York: Cambridge University Press.

Przeworski, Adam; Alvarez, Michael; Cheibub, José Antonio; Limongi, Fernando. 2000. Democracy and Development: Political Institutions and Well-Being in the World, 1950-1990. Cambridge: Cambridge University Press. Rueschemeyer, Dietrich; Stephens, Evelyne Huber; Stephens, John. 1992. Capitalist Development Eீ Democracy. Chicago: Chicago University Press.

Runciman, David. 2018. Como a democracia chega ao fim. São Paulo: Todavia. Schedler, Andreas. 1998. What is democratic consolidation. Journal of Democracy, v. 9, n. 2, pp. 91-107.

Schumpeter, Joseph. 1942. Capitalism, Socialism and Democracy. New York: Harper \& Brother.

Svolik, Milan. 2008. Authoritarian reversals and democratic consolidation. American Political Science Review, v. 102, n. 2, pp. 153-168.

Therborn, Göran. 1977. The rule of capital and the rise of democracy. New Left Review, n. 103, pp. 3-41.

Tilly, Charles. 2007. Democracy. Cambridge: Cambridge University Press. 


\section{A DEMOCRACIA NÃO ESTÁ MORRENDO: FOI 0 NEOLIBERALISMO QUE FRACASSOU}

\section{LUIZ CARLOS BRESSER-PEREIRA}

Resumo: A tese que a democracia está morrendo aos poucos aplica-se a países como a Hungria, a Polônia e a Turquia; não aos países ricos cuja democracia está consolidada por razões estruturais e pelos interesses envolvidos. A democracia foi uma conquista do povo que incomoda as elites, mas nem elas nem o povo querem substitui-la por um regime autoritário. Essa tese desvia a atenção do verdadeiro problema que os países desenvolvidos enfrentam: o fracasso do neoliberalismo e da teoria econômica neoclássica que o justifica. É esse fracasso, junto ao aumento dos exilados políticos e dos imigrantes e a perplexidade do mundo rico diante do desenvolvimentismo da China, que está dando origem ao populismo de direita e a um mal-estar generalizado no Ocidente.

Palavras-chave: Democracia; Neoliberalismo; Populismo; Povo; Elites; Ocidente.

\section{DEMOCRACY IS NOT DYING: IT WAS NEOLIBERALISIM THAT FAILED}

Abstract: The thesis that democracy is slowly dying applies to countries like Hungary, Poland, and Turkey; not to rich countries whose democracy is consolidated for structural reasons and for the interests involved. Democracy was a conquest of the people that bothers the elites, but neither the elite nor the people want to replace it by an authoritarian regime. This thesis diverts attention from the real problem faced by developed countries: the failure of Neoliberalism and the neoclassical economic theory justifying it. Such failure, alongside the growing number of political exiles and immigrants and the rich-world perplexity towards Chinese 
Resumos | Abstracts

developmentalism, is generating the right-wing populism and widespread malaise in the West.

Keywords: Democracy; Neoliberalism; Populism; People; Elites; West. Recebido: 20/08/2020 Aprovado: 27/10/2020 